\title{
Retinoblastoma cN1 TNM Finding v7
}

National Cancer Institute

\section{Source}

National Cancer Institute. Retinoblastoma CN1 TNM Finding v7. NCI Thesaurus. Code C88772.

Retinoblastoma with regional lymph node involvement (preauricular, cervical, submandibular). (from AJCC 7th Ed.) 